\title{
Inhibition by Normal Rabbit Sera of the Growth of T-mycoplasma Strains Isolated from Different Animal Species
}

\author{
By C. J. HOWARD AND R. N. GOURLAY \\ Agricultural Research Council, Institute for Research on Animal Diseases, \\ Compton, Newbury, Berkshire
}

(Received 2 February 1973; revised 30 April 1973)

S UMMARY

Normal rabbit sera contain a factor that, in conjunction with a heat labile component of guinea-pig or foetal calf serum, prevented the growth of human and other T-mycoplasmas but had little or no effect on bovine T-mycoplasmas examined. Susceptibility of human strains to the action of this substance was altered by growth in different media. The possibility that the factor might be antibody is discussed.

\section{INTRODUCTION}

During an investigation of the antigenic structure of $T$-mycoplasmas using the metabolic inhibition (m.i.) test, it was found that certain normal rabbit sera contained what appeared to be m.i. antibody to some T-mycoplasma strains. This phenomenon was investigated further since it might lead to considerable confusion in the use and interpretation of the m.i. test for examining the serology of $\mathrm{T}$-mycoplasmas.

\section{METHODS}

T-mycoplasma strains. The human strains, CD573, CD343, CD408, MI26/68, REOW, simian strain sp. I625A and canine strain sp. I70I, have been described previously (Howard \& Gourlay, 1972). Those human strains not described in the last study - strains 7, 23, 27, 58, 354, Pirillo, Cook and T960-were obtained from Dr F. T. Black, Aarhus, Denmark (Black, I97I).

The bovine strains, A4I7, D48, vic9, MmbI43 and Gra383, were isolated from pneumonic calf lungs. Strain F8o I was isolated from the urogenital tract of a cow and strain oI 3 from the eye of a cow with keratoconjunctivitis. Bovine T-mycoplasmas were purified by filtering (Millipore, $450 \mathrm{~nm}$ pore size) broth cultures and picking single colonies, on three successive occasions.

Sera. Normal rabbit sera were used throughout unless stated otherwise. Rabbit sera A, $\mathrm{B}$ and $\mathrm{C}$ were from New Zealand white rabbits bred at Compton. Wild rabbit sera $\mathrm{I}$ and 2 were provided by Mr P. Matthews (ARC, Compton). New Zealand rabbit serum D, Himalayan rabbit serum and a normal rabbit serum pool were provided by Dr R. H. Leach (Mycoplasma Reference Laboratory, Colindale, London). Normal rabbit serum was also obtained from Flow Laboratories (Irvine, Scotland). All rabbit sera were stored at $-20{ }^{\circ} \mathrm{C}$ and heated at $56^{\circ} \mathrm{C}$ for $30 \mathrm{~min}$ before use.

Guinea-pig serum was a pool from five Hartley strain animals. Small volumes stored at $-70{ }^{\circ} \mathrm{C}$ were thawed, used once and discarded. 
Serum collected from calves killed at Compton and aged one to six days at slaughter was stored at $-20{ }^{\circ} \mathrm{C}$ and filtered (Millipore, $220 \mathrm{~nm}$ pore size) before use.

Antisera. The rabbit antisera used here have been described previously (Howard \& Gourlay, 1972).

Rat antisera were raised against the human T-mycoplasma strains Pirillo and 58 grown in U2 broth (defined below), and strain Pirillo grown in TR medium (defined below). The organisms were harvested from $800 \mathrm{ml}$ of broth culture by centrifugation at $20000 \mathrm{~g}$ for $45 \mathrm{~min}$, washed three times by resuspension in $0.15 \mathrm{M}$-phosphate buffered saline, $\mathrm{pH} 7 \cdot 2$, resuspended in $2 \mathrm{ml}$ of buffered saline and used as antigen. Equal volumes of antigen and sodium alginate $(4 \%, \mathrm{w} / \mathrm{v}$; Boots, Nottingham) were mixed together and inoculated intramuscularly in I ml volumes into rats. After I 2 and I4 days the rats were inoculated intraperitoneally with 0.5 and $\mathrm{I} \cdot 0 \mathrm{ml}$ volumes respectively of antigen without alginate. Animals were bled 5 days after the last injection, the serum stored at $-20^{\circ} \mathrm{C}$ and heated at $56^{\circ} \mathrm{C}$ for 30 min before use.

Media. Unless stated otherwise, U2 broth (Gourlay, Brownlie \& Howard, I973) was used for growth of strains throughout; the constituents, given as final concentrations of $\mathrm{U}_{2}$ broth, are: $15 \%, \mathrm{v} / \mathrm{v}$, foetal calf serum (Flow); $40 \%, \mathrm{v} / \mathrm{v}$, Hanks balanced salt solution (Wellcome, Beckenham, Kent); $20 \%$, v/v, Hartley's digest broth; $0.5 \%$ yeast extract (Difco, Detroit, Michigan, U.S.A.); 1000 units penicillin $/ \mathrm{ml} ; 0.025 \%$ thallium acetate; $0.002 \%$ phenol red; $0.05 \%$ urea, $\mathrm{pH} \mathrm{6.2}$. The volume was made up by adding deionized glass-distilled water. Agarose, $0.9 \%$ (Miles-Seravac, Maidenhead, Berkshire) was added to make solid media.

Calf serum or horse serum (Wellcome no. 3) was substituted for foetal calf serum as stated in the text.

TR medium was as described by Taylor-Robinson, Martin-Bourgon, Watanabe \& Addey (I97I) except that yeast extract (Difco) and horse serum were used in place of an aqueous extract of Distillers Co. Ltd, dried yeast and Wellcome horse serum no. 6.

Unheated animal sera were used in media for growth of strains for use as antigen but heated $\left(56^{\circ} \mathrm{C}, 30 \mathrm{~min}\right)$ animal sera were included in media used in the m.i. tests.

The metabolic inhibition (m.i.) test. The basic test used was a slight modification of the m.i. test of Purcell, Taylor-Robinson, Wong \& Chanock (1966). Doubling serum dilutions of $25 \mu \mathrm{l}$ volume were made in $\mathrm{U}_{2}$ broth using a microtitre system (Cooke Engineering Co., Flow). As antigen, $25 \mu \mathrm{l}$ volumes of an overnight culture of organisms diluted I/10, I/IOO and $\mathrm{r} / \mathrm{1} 000$ in $\mathrm{U}_{2}$ broth, were added to the wells containing the serial dilutions of sera. Finally $50 \mu 1$ volumes of fresh $\mathrm{U}_{2}$ broth were added to each well. When guinea-pig serum was added to the system it was included in this final $50 \mu \mathrm{l}$ of medium. Titres were recorded as the reciprocal of the highest dilution of serum that inhibited growth of T-mycoplasmas according to Purcell et al. (I966). Titres were read when the $\mathrm{pH}$ of control wells, which did not contain antibody, gave a distinct colour change, about one $\mathrm{pH}$ unit. Use of an actively growing organism as antigen in the m.i. test results in the titre of a serum apparently decreasing with further incubation, as noted by Purcell et al. (I966). By using various dilutions of antigen-broth culture at least one antigen dilution can be expected to give the desired amount of colour change in control wells after overnight incubation, and the results of this are used for the test. 
Table I. The metabolic inhibition titre of normal rabbit sera against four T-mycoplasma strains

\begin{tabular}{|c|c|c|c|c|c|c|c|c|}
\hline \multirow[b]{3}{*}{ Rabbit serum } & \multicolumn{8}{|c|}{ T-mycoplasma strain* } \\
\hline & \multicolumn{4}{|c|}{ Guinea-pig serum absent } & \multicolumn{4}{|c|}{ Guinea-pig serum, $0.5 \%$} \\
\hline & 58 & Pirillo & T960 & A417 & 58 & Pirillo & T960 & A4 17 \\
\hline New Zealand D & $<\mathrm{IO}$ & $<$ IO & $<10$ & $<10$ & 640 & 640 & 640 & $<10$ \\
\hline Himalayan & $<\mathrm{IO}$ & $<$ IO & $<10$ & $<10$ & 160 & 320 & 160 & $<$ IO \\
\hline Pool I & $<10$ & $<$ IO & $<$ IO & 40 & 320 & 320 & I 60 & 40 \\
\hline Pool 2 & $<$ IO & $<$ IO & $<10$ & 10 & 640 & 320 & I 60 & 10 \\
\hline Wild I & $<10$ & $<10$ & $<$ IO & 20 & 160 & 80 & 40 & 10 \\
\hline Wild 2 & $<10$ & $<10$ & $<10$ & $<$ IO & 160 & 160 & 320 & $<10$ \\
\hline
\end{tabular}

* Strain A4I7 is a bovine T-mycoplasma. The remainder are human isolates.

Table 2. The metabolic inhibition titre of three normal rabbit sera against human T-mycoplasmas in a system containing $0.5 \%$ guinea-pig serum

T-mycoplasma
strain
7
23
27
58
354
Pirillo
Cook
T960
CD573
CD343
CD408
MI $26 / 68$
REOW

\begin{tabular}{rrr}
\multicolumn{3}{c}{ Normal rabbit serum* } \\
A & \multicolumn{1}{c}{ B } & C \\
640 & I 60 & 320 \\
2560 & 1280 & 2560 \\
1280 & 1280 & 1280 \\
1280 & 2560 & 1280 \\
2560 & 1280 & 2560 \\
640 & 640 & 640 \\
640 & 1280 & 2560 \\
$>10240$ & 320 & 1280 \\
640 & 640 & 320 \\
1280 & 640 & 1280 \\
40 & 80 & 80 \\
320 & 320 & 640 \\
160 & 160 & 320
\end{tabular}

* The titres of the rabbit sera were $<10$ in the absence of guinea-pig serum.

\section{RESULTS}

Dependence on a heat labile co-factor for metabolic inhibition by normal rabbit serum

The following preliminary experiments defined the nature of the phenomenon.

The m.i. titre of normal rabbit serum tested against human T-mycoplasma strain Pirillo was $<5$ in the absence of added guinea-pig serum. When guinea-pig serum was added to give final concentrations of $0.25,0.5, \mathrm{I} \cdot 0,2 \cdot 0$ and $4.0 \%$, the m.i. titres were $80,320,320$, 320 and 640 respectively. However, guinea-pig serum added at concentrations greater than $0.5 \%$ inhibited the growth of human strain T960 and bovine strains A4I7 and Mmbi43. In subsequent use at $0.5 \%$ it had no detectable effect on the growth of any human or bovine strains.

If guinea-pig serum was heated at $56{ }^{\circ} \mathrm{C}$ for $30 \mathrm{~min}$ before being added to give a final concentration of $0.5 \%$, the titres of the normal rabbit sera $\mathrm{A}$ and $\mathrm{B}$ were $<5$ against human strain Pirillo. All experiments performed to measure the m.i. titre of normal rabbit serum used $\mathrm{U}_{2}$ broth containing foetal calf serum that had been heated at $56{ }^{\circ} \mathrm{C}$ for $30 \mathrm{~min}$. However, when unheated foetal calf serum was used in U2 broth instead of heated serum, 
Table 3. The metabolic inhibition titre of three normal rabbit sera against bovine, simian and canine T-mycoplasmas

\begin{tabular}{|c|c|c|c|c|c|c|}
\hline \multirow{3}{*}{$\begin{array}{l}\text { T-mycoplasma } \\
\text { strain }\end{array}$} & \multicolumn{6}{|c|}{ Normal rabbit serum } \\
\hline & \multicolumn{3}{|c|}{ Guinea-pig serum absent } & \multicolumn{3}{|c|}{ Guinea-pig serum, $0.5 \%$} \\
\hline & A & B & $\mathrm{C}$ & A & B & $\mathrm{C}$ \\
\hline A417 (bovine) & 20 & 20 & 20 & 20 & 20 & IO \\
\hline D48 (bovine) & 20 & 20 & 20 & IO & IO & IO \\
\hline vic9 (bovine) & 10 & 10 & $<10$ & $<10$ & $<10$ & $<10$ \\
\hline Mmbi43 (bovine) & 20 & 20 & IO & 10 & IO & $<10$ \\
\hline Gra383 (bovine) & 20 & 20 & IO & $<$ IO & $<$ IO & IO \\
\hline F80 I (bovine) & $<10$ & $<$ IO & $<$ IO & $<10$ & $<$ IO & $<10$ \\
\hline or 3 (bovine) & $<$ IO & $<10$ & $<$ IO & $<\mathrm{IO}$ & $<10$ & $<$ IO \\
\hline Simian sp. I625A & 20 & $<10$ & $<$ I0 & 320 & $\mathrm{I} 60$ & I 280 \\
\hline Canine sp. I 701 & $<\mathbf{1 0}$ & $<10$ & $<$ IO & 640 & 640 & 640 \\
\hline
\end{tabular}

it was not necessary to add guinea-pig serum to demonstrate a m.i. titre in normal rabbit serum.

Differences in the growth phase of bacteria can affect their susceptibility to antibody and complement (Rowley \& Wardlaw, 1958); however, no difference was apparent in m.i. titres of normal rabbit serum against overnight cultures and cultures that had been kept at $-70{ }^{\circ} \mathrm{C}$.

\section{The metabolic inhibition titre of different normal rabbit sera}

In order to examine the distribution of this inhibiting factor in different normal rabbit sera, six rabbit serum samples were tested for activity against one bovine and three human T-mycoplasmas (Table I). All six samples possessed m.i. activity against the three human strains in the presence of guinea-pig serum; a small variation in the $\mathrm{m}$.i. titres was evident. A low or negative m.i. titre against the bovine strain $\mathrm{A} 4 \mathrm{I} 7$ was found in the presence or absence of guinea-pig serum.

Variation in the metabolic inhibition titre of normal rabbit serum for different T-mycoplasma strains

The m.i. titres of three normal rabbit sera (A, B, C) were measured against I 3 human T-mycoplasma strains (Table 2). If guinea-pig serum was not added to the system the titres of the sera were all $<$ IO. The three sera did not differ greatly in their titre against a particular strain. However, there were some variations in m.i. titre using different strains, although all human strains were affected.

The three normal rabbit sera gave m.i. titres of $₹ 20$ to all bovine strains in the absence of added guinea-pig serum (Table 3). The titres were no higher when guinea-pig serum was added. Thus as a group the bovine strains appear to be resistant to the factor in normal rabbit serum that affects human strains.

The m.i. titre of normal rabbit sera was demonstrated against the canine and simian strains only in the presence of guinea-pig serum (Table 3 ). Thus these two strains reacted in the same way as the human strains. 
Table 4. Effect of growth of three human T-mycoplasmas in different media on the metabolic inhibition titre of a normal rabbit serum

T-mycoplasma
strain

58

Pirillo

T960
Medium

U2 broth + FCS
U2 broth + CS
U2 broth + HS
TR medium

$\mathrm{U} 2$ broth + FCS

$\mathrm{U}_{2}$ broth $+\mathrm{CS}$

$\mathrm{U} 2$ broth $+\mathrm{HS}$

TR medium

$\mathrm{U}_{2}$ broth + FCS

U2 broth + CS

$\mathrm{U} 2$ broth $+\mathrm{HS}$

TR medium
Titre*

640

160

320

$<$ 10

320

80

80

$<$ IO

640

I 60

320

$<$ IO

* Normal rabbit serum $(C)$ was tested in the presence of $0.5 \%$ guinea-pig serum; the serum titre was $<\mathrm{IO}$ in the absence of guinea-pig serum.

FCS, foetal calf serum; CS, calf serum; HS, horse serum.

Table 5. Metabolic inhibition titre of rat antisera against human T-mycoplasma strains 58 and Pirillo grown in $U_{2}$ broth and TR medium

\begin{tabular}{|c|c|c|c|c|c|}
\hline & & \multicolumn{4}{|c|}{ Strain* used for MI test } \\
\hline \multicolumn{2}{|c|}{ Rat antisera against } & \multicolumn{2}{|c|}{ Guinea-pig serum absent } & \multicolumn{2}{|c|}{ Guinea-pig serum, $0.5 \%$} \\
\hline Strain & Grown in & Pirillo & 58 & Pirillo & 58 \\
\hline $\begin{array}{l}\text { Pirillo } \\
58\end{array}$ & $\begin{array}{l}\mathrm{U}_{2} \text { broth } \\
\mathrm{U}_{2} \text { broth }\end{array}$ & $\begin{array}{r}80 \\
<\quad 10\end{array}$ & $\begin{array}{r}10 \\
160\end{array}$ & $\begin{array}{r}320 \\
<10\end{array}$ & $\begin{array}{l}<10 \\
640\end{array}$ \\
\hline Pirillo & TR medium & 320 & IO & 320 & IO \\
\hline
\end{tabular}

* Organisms used in m.i. test were grown in $\mathrm{U}_{2}$ broth.

\section{Effect of growth in different media}

The m.i. titre of normal rabbit serum had been demonstrated using T-mycoplasmas grown and tested in $\mathrm{U}_{2}$ broth, and so the possibility that variations in the growth medium might affect the ability of normal rabbit serum to inhibit T-mycoplasmas was examined (Table 4). A m.i. titre was demonstrated in normal rabbit serum for the three human strains grown and tested in $\mathrm{U}_{2}$ broth, or grown and tested in $\mathrm{U}_{2}$ broth in which calf serum or horse serum had been substituted for foetal calf serum. No m.i. titre was demonstrated in normal rabbit serum for the same T-mycoplasmas grown and tested in TR medium.

\section{Immunization of rats}

It was possible that the m.i. titre of normal rabbit serum for human strains grown in U2 broth might be because normal rabbit serum contained antibody to an antigen which was present in all the human strains tested when they were grown in $\mathrm{U}_{2}$ broth, but not when grown in TR medium. The antisera from rats immunized with strains Pirillo and 58 grown in $\mathrm{U}_{2}$ broth, and strain Pirillo grown in TR medium, were tested by the m.i. test for activity against the same two strains grown in $U_{2}$ broth (Table 5). Rats were chosen because an initial investigation had failed to demonstrate the presence of a factor in their sera comparable to the one found in normal rabbit sera. The antisera were specific for the strains against which 
Table 6. Metabolic inhibition titre of specific antisera against bovine and simian T-mycoplasmas tested against human, simian and canine strains without added guinea-pig serum

\begin{tabular}{llcccr}
\multicolumn{5}{c}{ Antiserum to strains } \\
$\begin{array}{l}\text { T-mycoplasma } \\
\text { strain }\end{array}$ & $<20$ & vic9 & OI 3 & $\begin{array}{r}\text { Simian } \\
\text { sp. I625A }\end{array}$ \\
CD573 (human) & $<20$ & $<20$ & $<20$ & $<20$ & $<20$ \\
CD343 (human) & $<20$ & 40 & 20 & 20 & 40 \\
CD408 (human) & $<20$ & $<20$ & 40 & $<20$ & $<20$ \\
MI26/68 (human) & $<20$ & 20 & 20 & $<20$ & $<20$ \\
REOW (human) & $<20$ & $<20$ & 20 & $<20$ & $<20$ \\
Simian sp. I625A & $<20$ & $<20$ & $<20$ & $<20$ & 2560 \\
Canine sp. I70I & $<20$ & $<20$ & $<20$ & $<20$ & $<20$
\end{tabular}

they were raised, independent of the medium in which the antigen was prepared. The m.i. titres of two of the antisera were slightly higher in the presence of $0.5 \%$ guinea-pig serum than when tested in a system from which guinea-pig serum was omitted.

\section{Attempt to characterize the factor in normal rabbit serum}

Three methods were used to see whether the properties of the factor in normal rabbit serum were consistent with it being antibody. I. An attempt was made to remove the inhibitory activity of normal rabbit serum by absorption. Human T-mycoplasmas Pirillo and 58 were grown in $U_{2}$ broth in the same way as for the immunization of rats and used in an attempt to absorb the active component from normal rabbit serum. Normal rabbit serum $\mathrm{C}(\mathrm{O} . \mathrm{I} \mathrm{ml})$ and $0.4 \mathrm{ml}$ of $\mathrm{T}$-mycoplasma suspension were incubated together at $4{ }^{\circ} \mathrm{C}$ for $24 \mathrm{~h}$. The mixture was then centrifuged at $20000 \mathrm{~g}$ for $45 \mathrm{~min}$, heated at $56^{\circ} \mathrm{C}$ for $30 \mathrm{~min}$ and tested, in the presence of guinea-pig serum, for activity in the m.i. test against strains Pirillo and 58 . No absorption of the active component was detectable. 2. Further characterization of the factor was attempted by sodium sulphate fractionation of normal rabbit serum. Normal rabbit serum $(2.5 \mathrm{ml})$ from New Zealand rabbit A was treated with $12 \% \mathrm{w} / \mathrm{v}$ sodium sulphate at $37^{\circ} \mathrm{C}$ to precipitate the $\gamma$-globulins (Kekwick, I940). The precipitate was finally dissolved in $2.5 \mathrm{ml}$ of water and dialysed at $4{ }^{\circ} \mathrm{C}$ against $0.15 \mathrm{M}$-phosphate buffered saline, $\mathrm{pH} 7 \cdot 2$. The m.i. titre of the sodium sulphate precipitate tested against strains Pirillo and 58 in a system containing $0.5 \%$ guinea-pig serum was 320 and I60 respectively. 3 . Finally it was reasoned that if the factor was antibody it should be possible to demonstrate it binding to colonies of the human T-mycoplasmas by immunofluorescence. An attempt to demonstrate the binding of the inhibitory factor in normal rabbit serum to colonies on agar of strains Pirillo, $5^{8}$ and T960 by the method of Rosendal \& Black (1972) proved negative.

Metabolic inhibition titre of specific antisera to bovine and simian T-mycoplasma strains tested against human, simian and canine strains

Because of these new findings with normal rabbit sera it seemed likely that the m.i. titres of rabbit antisera, when tested against human, canine and simian strains (Howard \& Gourlay, 1972), were due to the inhibitory factor in normal rabbit serum and not to the presence of common antigens on bovine and human T-mycoplasmas. The antisera used by Howard \& Gourlay (1972) were therefore retested for activity in a system from which guinea-pig serum was omitted, in order to avoid confusion by this normal rabbit serum 
factor (Table 6). No extensive cross-reactions between strains from different animal species could be demonstrated. However, some of the antisera to bovine strains gave low titres $(\gtrless 40)$ against certain human strains. Rabbit antisera had high $\mathrm{m}$.i. titres when tested against homologous organisms in the absence of guinea-pig serum (C. J. Howard \& R. N. Gourlay, unpublished).

The titres of rabbit antisera to bovine T-mycoplasmas were measured against non-bovine strains grown in TR medium and tested in TR medium containing $0.5 \%$ guinea-pig serum. The titres observed were virtually identical to the titres recorded in Table 6 for U2 brothgrown organisms. The only difference of greater than one dilution for organisms grown in TR medium was seen with antiserum to bovine T-mycoplasma vic9, which had a titre of $<20$ to human strain CD408 and 40 to the canine T-mycoplasma.

\section{DISCUSSION}

Our finding that all normal rabbit sera tested contain a factor, which survives heating at $56{ }^{\circ} \mathrm{C}$ for $30 \mathrm{~min}$, and which inhibits the growth of T-mycoplasmas in the m.i. test (providing a heat labile co-factor is present) could be explained if normal rabbit serum contains antibody that in the presence of complement inhibits the growth of, or kills, certain T-mycoplasmas. This hypothesis is consistent with the precipitation of the active component with the $\gamma$-globulin fraction by sodium sulphate. Antibody, in conjunction with complement, kills T-mycoplasmas (Lin \& Kass, 1970). Also normal rabbit sera contain antibody to other species of mycoplasmas, namely Mycoplasma pneumoniae and M. hominis (Brunner, James, Horswood \& Chanock, 1972).

Conflicting evidence on the nature of the factor comes from our inability to demonstrate antibody in normal rabbit serum either by immunofluorescence (although this may be because the test was not sensitive enough) or by absorption. Failure to absorb the factor with antigen might have been because the method used was ineffective.

It is improbable that the normal rabbit serum possessed similar amounts of antibody to all of the seven strains proposed as separate serotypes of human T-mycoplasmas by Black (I97I), unless the human strains possessed a common antigen when grown in U2 broth but not when grown in TR medium. This possibility would be consistent with the finding that the m.i. titre of normal rabbit serum was only demonstrable against strains grown in U2 broth. However, the immunization of rats with strains grown in the two media failed to demonstrate a common antigen, whether synthesized by the organisms or present as an absorbed medium component. Bradbury \& Jordan (1972) demonstrated by immunization the presence of immunoglobulins adsorbed from the medium on to Mycoplasma gallisepticum. The alternative method of absorption was ineffective in our hands and it was not possible to demonstrate a common antigen in normal rabbit serum by this approach. Clearly more work is needed to identify the T-mycoplasmacidal factor in rabbit serum and to determine the relationship between it and antibody.

The mycoplasmacidal substance in tissue reported by Kaklamanis, Thomas, Stravropoulos, Borman \& Boshwitz (1969), suggested to be lysolecithin, differs from our factor in normal rabbit serum which requires a heat labile co-factor and is only effective against certain strains. It appears distinct from the substance found in bull serum and semen by TaylorRobinson, Thomas \& Dawson (1969) which, unlike the rabbit serum factor, inhibited bovine T-mycoplasmas. Some similarities exist between our factor and that reported by Roberts (197I), who found the inhibitory action of certain fresh animal sera was not confined to any particular serotype. The substance in bovine sera which inhibited human mycoplasmas 
(Smith \& Morton, I953) is also similar to the factor found in normal rabbit sera, as both require a heat labile co-factor.

The difference in the susceptibility of human strains to normal rabbit serum when grown in different media explains the divergence between our results and those of others concerning apparent serological cross-reactions between T-mycoplasmas isolated from different animal species, and means that the results of Howard \& Gourlay (1972) must be interpreted differently. Since the bovine strains are not affected by this factor the conclusions concerning them remain unchanged, but the m.i. titres to human strains found in antisera against bovine strains of as high as $>320$ (Howard \& Gourlay, 1972) should be attributed principally to the normal serum factor and not to the presence of common antigens on the bovine and human strains, as the same sera retested here against the same strains only had m.i. titres of $₹ 40$. These results were for organisms grown and tested in U2 broth in the absence of guinea-pig serum, or grown and tested in TR medium in the presence of guineapig serum. Although the cross-reactions between T-mycoplasma strains isolated from different animal species are not as extensive as was originally concluded, low level cross-reactions between strains isolated from different animal species do appear to be genuine and have also been observed by Taylor-Robinson et al. (I97I).

The finding that normal rabbit serum had an m.i. titre against all the human and the canine and simian T-mycoplasmas unites them as a group and distinguishes them from the bovine strains, and is one of the few indications that differences exist between T-mycoplasmas isolated from different animal species.

We would like to thank Miss J. Wren for excellent technical assistance.

\section{REFERENCES}

BLACK, F. T. (197I). Serological methods for classification of human T-mycoplasmas. In V. Internationaler Kongress für Infektionsktionskrankheiten, Vienna, 1970, vol. I. Virus: Mycoplasma and L-Forms etc., pp. 407-4II. Vienna: Wiener Medizinischen Akademie.

Bradbury, J. M. \& Jordan, F. T. W. (1972). Studies on the adsorption of certain medium proteins to Mycoplasma gallisepticum and their influence on agglutination and haemagglutination reactions. Journal of Hygiene 70, 267-278.

Brunner, H., James, W. D., Horswood, R. L. \& Chanock, R. M. (1972). Measurement of Mycoplasma pneumoniae mycoplasmacidal antibody in human serum. Journal of Immunology 108, I49I-I498.

Gourlay, R. N., Brownlie, J. \& Howard, C. J. (1973). Isolation of T-mycoplasmas from goats, and the production of sub-clinical mastitis in goats by the intramammary inoculation of human T-mycoplasmas. Journal of General Microbiology 76, 25I-254.

Howard, C. J. \& Gourlay, R. N. (I972). Serology of bovine T-mycoplasmas. British Veterinary Journal 128, xxXvii-xli.

Kaklamanis, E., Thomas, L., Stravropoulos, K., Borman, I. \& Boshwitz, C. (1969). Mycoplasmacidal action of normal tissue extracts. Nature, London 221, 860-862.

KEKWICK, R. A. (1940). The serum proteins in multiple myelomatosis. Biochemical Journal 34, I248-1257.

LIN, J.-S. \& KAss, E. H. (1970). Immune inactivation of T-strain mycoplasmas. Journal of Infectious Diseases I22, $93-95$.

Purcell, R. H., Taylor-Robinson, D., Wong, D. \& Chanock, R. M. (1966). Color test for the measurement of antibody to T-strain mycoplasmas. Journal of Bacteriology 92, 6-I 2.

RoBERTS, D. H. (I97I). Interaction of porcine mycoplasmas with fresh animal serum. Journal of Hygiene $6 \mathbf{9}$, $36 \mathrm{I}-368$.

Rosendal, S. \& Black, F. T. (1972). Direct and indirect immunofluorescence of unfixed and fixed mycoplasma colonies. Acta pathologica et microbiologica Scandinavica, section B 80, 61 5-622.

Rowley, D. \& WARDLAw, A. C. (1958). Lysis of gram-negative bacteria by serum. Journal of General Microbiology 18, 529-533. 
SMith, P. F. \& MoRton, H. E. (1953). Nature of growth inhibitor in some mammalian sera for pleuropneumonia-like organisms of human origin. Proceedings of the Society for Experimental Biology and Medicine 83, 65-69.

Taylor-Robinson, D., Martin-Bourgon, C., Watanabe, T. \& AdDey, J. P. (1971). Isolation of T-mycoplasmas from dogs and squirrel monkeys: biological and serological comparison with those isolated from man and cattle. Journal of General Microbiology 68, 97-107.

Taylor-Robinson, D., Thomas, M. \& Dawson, P. L. (1969). The isolation of T-mycoplasmas from the urogenital tract of bulls. Journal of Medical Microbiology 2, 527-533. 